\title{
Laundromax: An Entrepreneurial Business Case Study
}

\author{
Keith Cobb, (E-mail: kcobb@cobbcorner.com), \\ Tom Tworoger, (E-mail: tworoger@huizenga.nova.edu), Nova Southern University
}

Robert C. Preziosi, (E-mail: preziosi@ huizenga.nova.edu), Nova Southern University

\section{THE DECADE OF THE 1990S AND ENTREPRENEURIAL OPPORTUNITY}

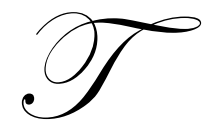

he decade of the 1990s was a golden era for entrepreneurship in the United States. The economy was flourishing, and the "dot com" boom fueled unparalleled private equity investment throughout the decade. Start-up companies abounded, especially in the technology industry, and there seemed to be an insatiable appetite for investment in emerging and developing companies.

In the midst of this feverish activity, the image of small business began to change. Once shunned by big money, small business suddenly was the darling of Wall Street. Entrepreneurs and investors were looking at every type of small business as an opportunity for "roll-up" or consolidation, believing that economies of scale and synergies would yield extraordinary profits. Financing for these ventures was plentiful. Indeed, a few high profile consolidations like Waste Management and AutoNation had been successful. These successes further stirred up new interest, and private equity investors poured capital into thousands of deals at unprecedented levels.

\section{The Birth of Laundromax}

Alan Reese and Eric Mounger watched the consolidation phenomenon with great interest in the early 1990s. They were both well-educated, energetic executives who had considerable experience with highly successful consolidators - Blockbuster Entertainment and AutoNation. They both had the entrepreneurial itch and wanted to build something for themselves. So they joined forces and decided to leave their intense corporate environments behind. They agreed to resign their jobs, combine their talents and experience and launch their own new business.

Reese and Mounger favored retail and service industries, where they had experience, and were looking for a business that could be consolidated or "rolled up" on a nationwide scale. They were both ambitious individuals and, accordingly, they aimed high. After considerable research into a variety of business models, they decided on the coin laundry business, which they concluded presented a highly attractive retail opportunity. The concept was simple and straightforward, it had high profit margins in the 30-40\% range, it was a cash business with virtually no inventories and the industry was highly fragmented,. Neither had direct experience in the laundry industry or in entrepreneurial management; however, they both had deep backgrounds in business analysis, mergers and acquisitions and rapid business roll-outs. At the time, Reese and Mounger were 32 and 29 years old, respectively.

\section{THE INDUSTRY}

Laundromat customers exist in virtually every community in the United States, particularly in lower income areas in which residents do not have laundry facilities in their homes. Coin operated laundry represents an over $\$ 3$ billion revenue industry characterized by steady, non-cyclical demand. There are 25,000-30,000 laundry facilities nationwide. The industry is highly fragmented, with only $4 \%$ of laundromats operated by companies or individuals that own more than five stores - truly a "mom and pop" industry. Existing stores tend to have older coin operated machines. Their smaller facilities provide few conveniences. The typical laundry occupies 1,500-2,000 square feet and has less than 30 machines. The facilities are often unattractive, unclean and generally in difficult to access locations. Despite these negative characteristics, the industry has consistently enjoyed relatively high profit margins. A high repeat customer business with no accounts receivable and lacking a nation-wide Wall Mart type of big box 
competitor helped keep the margins high. One important characteristic of the market that Reese and Mounger missed was that the market had virtually no growth. Their customers would have to come at the expense of their competitors.

\section{THE VISION}

Reese and Mounger envisioned a new paradigm. They saw a new, superior facility that would be clean, modern, conveniently located and highly attractive to customers. Their vision was modeled somewhat after Blockbuster, where they both had worked as Blockbuster blanketed the country with consumer friendly stores. They believed a new super-store platform, combined with modern technology, sophisticated marketing and skilled management would yield even greater profit margins. Accordingly, they proceeded to develop a plan for more than 650 company-owned stores nationwide, supplemented with 300 franchised locations. They saw national branding as a differentiating marketing advantage. As the company grew, they expected to see important benefits from name recognition - higher customer traffic, increased leverage with landlords and greater bargaining power with contractors. The founders envisioned a business as ubiquitous as Walgreens in the major cities. The completed network would represent 8-10\% of the U. S. laundromat market. They stated in their Private Placement Offering Memorandum that 'Just as Blockbuster Entertainment transformed the 'mom' and 'pop' video rental industry, the company believes that its laundromat superstores will revolutionize the laundry industry". Armed with their rigorous research and ambitious vision, they launched Laundromax in June, 1997.

\section{STORE CONCEPT}

The typical Laundromax store was designed to have 80-100 washers and dryers and offer a full range of laundry services, including dry cleaning drop-off, wash and fold drop-off and detergent sales. The stores provided full-time attendants, air conditioning, televisions, juke boxes, video games, kids' play areas and vending machines in a bright and clean environment. They were designed to be the most convenient and comfortable laundry facilities in the industry.

Studies showed that larger capacity washing machines, despite the incremental cost, generated substantially more cash flow per square foot than the smaller machines typically found in existing laundromats. Moreover, research showed that customers prefer the larger equipment. Accordingly, Laundromax equipped its locations with a mixture of high capacity machines, designed to maximize cash flow. The stores were designed to use Smartcards, instead of coins. This innovation offered numerous advantages - customer convenience, reduced theft, reduced repair and maintenance, variable pricing capability and cash float instead of working capital consumption.

\section{COMPETITION}

Competition in local markets came primarily from the local "mom and pop" operators and, in some markets, from local and regional chains. The typical competitor owned one or two stores. Reese and Munger's research indicated that these stores had poorly maintained aging equipment operating in a dirty environment. Furthermore, the stores were considered unsafe by their customers. The typical laudromat used top-loading washers instead of the more modern and higher capacity front-loading machines.

The principal large store direct competitor was Spin Cycle, a company based in Scottsdale, Arizona. They launched their business about a year ahead of Laundromax. The Spin Cycle concept was similar to that of Laundromax with regard to size, store layout and added services. They opened approximately 170 units in 25 markets in their first three years. They reportedly had stumbled badly in the execution of their business plan and, accordingly, were facing formidable challenges. Laundromax investigated Spin Cycle's development, studied their strategies and tactics and attempted to learn from their early mistakes. After considerable research, Laundromax concluded that Spin Cycle's troubles were attributable to three major issues: (a) they expanded too fast in poor locations and failed to control construction costs, (b) they scattered their initial stores widely in 25 markets, making management and control of operations a challenge, and (c) they did not adopt the Smart Card concept and were believed to have suffered substantial losses from employee theft. 


\section{STORE LOCATIONS}

Laundromax used a sophisticated demographic mapping system to identify trade areas that offered attractive opportunities. The system was based on census data and growth estimates. It identified major traffic arteries, plotted all major competitors on a map and located significant shopping centers and retail areas. The company considered several criteria to be critical to the success of a location - a minimum of 10,000 renters within a 1-2 mile radius, median household income in the $\$ 15,000-40,000$ range, low to moderate levels of competition, at least 10 available parking spaces and close proximity to major retail activity with minimum traffic counts of 20,000 average cars per day.

\section{STORE ECONOMICS}

Store facilities were all leased, typically for five years with renewal options. Initial studies and projections targeted the average store cost at $\$ 500,000$ - approximately $40 \%$ for leasehold improvement and $60 \%$ for equipment. Generally, the company was able to finance $75 \%$ of the capital cost, once a store was open and operating.

Store revenue at full maturity was expected to average approximately $\$ 425,000$ per year. Operating profit at the store level (before corporate expenses) was budgeted at 25\% and EBITDA at $36 \%$ of revenue. Stores were expected to break even seven months after opening and reach full maturity in twelve months.

\section{CAPITALIZATION}

The founders devoted full time to the business and made nominal cash capital contributions to get the company up and running. They sought primary seed capital from private investors. They prepared a comprehensive business plan, complete with detailed financial projections, and presented their concept to dozens of sophisticated business people in South Florida and elsewhere. Potential investor reception was excellent, and only a small minority of those approached declined to invest. The founders were able to leverage their business contacts and relationships effectively and raised $\$ 7$ million from 63 private investors in 1997. These initial investors were issued common stock at $\$ 1.00$ per share.

The company recognized that the rapid roll-out of stores would require continued infusions of equity and debt capital during the early stages. At some point (which the founders projected at 100 stores) the stores would begin to generate enough cash flow to supplement future expansion.

Chewing up cash in the pre-operating and development stage, the company found itself again back in the capital markets in 1999. Management again chose the private placement route. This time they raised $\$ 10$ million from three venture capital firms and 29 private investors. Common stock was issued to these investors at $\$ 2.00$ per share, twice the initial offering price.

In addition to equity capital, the Company negotiated three major credit facilities with equipment manufacturers and commercial banks. These totaled \$18 million. Additionally, a construction loan for $\$ 6$ million was negotiated and in place by mid-2000.

Total capitalization in mid-2000 is summarized below: 


\begin{tabular}{|c|c|c|c|}
\hline & $\begin{array}{l}\text { Shares and } \\
\text { Options }\end{array}$ & $\begin{array}{l}\text { Ownership } \\
\text { Percent }\end{array}$ & $\begin{array}{c}\text { Cash } \\
\text { Contributed } \\
\end{array}$ \\
\hline \multicolumn{4}{|l|}{ Common stock: } \\
\hline Founders & $3,000,000$ & $20.0 \%$ & $\$ \quad 200,000$ \\
\hline Directors & $5,025,000$ & $33.5 \%$ & $8,150,000$ \\
\hline \multirow[t]{2}{*}{ Other investors } & $6,980,000$ & $46.5 \%$ & $8,855,000$ \\
\hline & $15,005,000$ & $100.0 \%$ & $\$ 17,205,000$ \\
\hline $\begin{array}{l}\text { Management and employee } \\
\text { options and warrants }\end{array}$ & $2,770,250$ & & - \\
\hline \multicolumn{4}{|l|}{ Debt: } \\
\hline Property and equipment loans & & & $\$ 24,000,000$ \\
\hline
\end{tabular}

\section{CORPORATE GOVERNANCE AND MANAGEMENT}

The Company formed a Board of Directors following the first capital offering. Six board members represented the approximately 85 equity investors; these board members themselves had invested over $\$ 8$ million. Board membership included: the former CEO of a major travel company; the chairman and CEO of a major Florida bank; the president of the nation's largest automotive retailer; the founding partner of a private investment group; the president of a venture capital firm; and the former chief operating officer of Blockbuster, Inc.; as well as the founders, Reese and Mounger.

Alan Reese served as President of the Company and Eric Mounger served as Chief Financial Officer. Other management personnel experienced in real estate and operations were hired as the business developed.

Alan Reese graduated from Dartmouth College and subsequently received a Master of Arts degree in English and American literature from the University of North Carolina. He later received his MBA from Columbia University. He spent three years on Wall Street as a mergers and acquisitions associate with Drexel Burnham Lambert. In 1993, Reese joined Blockbuster Entertainment as Director of Business Development. Following three years in that role, he joined AutoNation as Vice President of Corporate Development, working directly with their rapid acquisition of automobile dealerships.

Eric Mounger was a graduate of Barry University and did postgraduate work at Oxford University. He joined Blockbuster Entertainment in 1989 and worked in a number of roles over an eight year period, including mergers and acquisitions and corporate finance, and finally as Vice President of Product Administration in charge of product purchasing systems and product pricing negotiations with studio and label organizations. Following the sale of Blockbuster to Viacom, he worked for several months at AutoNation as Vice President of Corporate Development.

\section{EARLY OPERATIONS}

The founders immersed themselves in the business and began moving swiftly. They created designs for new state-of-the-art facilities - super stores with approximately 3,500 square feet and 80 or more modern washing and drying machines. Reese and Mounger also commissioned a location market study and launched the business simultaneously in five markets - South Florida, Atlanta, Boston, Memphis and New Orleans. These locations were chosen for their unique characteristics - test markets, more or less. They were looking for "proof of concept" before the nationwide rollout.

Sites were quickly acquired in these markets, and construction began in early 1998 . The first store opened in Miami in October, 1998. Four more were opened and ten existing stores were acquired for conversion prior to year 
end. During 1999 an additional 17 stores were opened. By mid-2000, Laundromax had 36 stores open and another 62 locations identified and in some stage of development.

Actual revenues and operating results of most developed stores roughly approximated the expectations set forth in the business plan. However, results in individual markets varied quite significantly. Moreover, the losers were more than just below average; they were big losers. Also, the ramp-up from opening to full maturity closely tracked the model, on average, but results varied widely from market to market. Studies of these results yielded some important observations about location demographics and management. For example, the concept didn't seem to work in Memphis, regardless of the tactics tried by management. On the other hand, the Boston locations were all winners. Critical lessons were being learned about pitfalls to avoid as the business expanded. Using these lessons, management continued to hone the model to set the stage for more uniform performance as the business grew.

Corporate expenses were high. They were planned this way. Management believed that the success of the business turned to a large extent on a large critical mass of stores and a nationwide roll-out. The sooner this critical mass was achieved, the sooner the profit rewards would start. Heavy corporate management, development and marketing expenses were required to achieve the necessary rapid expansion.

As the business progressed, management found the planned economies of scale to be elusive. Most of the usual efficiencies attributed to business consolidations (purchasing, marketing, etc.) turned out to be virtually inapplicable in this industry. The typical marketing strategies like media advertising embraced by many retailers, for example, didn't seem to be applicable to the local Laundromax market demographics. Therefore, the company lost much of the planned leverage from the high corporate expenses. Nevertheless, management was not thwarted. Although return on investment may not reach the extraordinary high levels in the plan, management reasoned that they would still exceed most expectations for emerging businesses.

In addition to the economies of scale problems, branding was turning out to be another elusive objective. How do you reach an unsophisticated market with annual incomes in the $\$ 25,000-\$ 35,000$ range? The aforementioned local demographics did not require store consistency as in the case of a McDonalds. The typically customer would visit the same laundromat every week. They didn't shop the competition. In fact, later researched indicated that the 2 hours spent in a laundromat were social in nature. The same people might be there every time you go there. The customer might even plan it that way. This, of course, added to the problem of stealing customers from the competition. Price incentives to lure customers would certainly affect profit margins

\section{FINANCIAL PERFORMANCE}

Selected financial data for the early stages of the company, coupled with projections for future years are shown below:

\begin{tabular}{|c|c|c|c|c|c|c|c|}
\hline & \multicolumn{2}{|c|}{ Historical } & \multicolumn{5}{|c|}{ Projected } \\
\hline & 1998 & $\underline{1999}$ & 2000 & 2001 & $\underline{2002}$ & 2003 & 2004 \\
\hline Total revenue & 462 & 5,273 & 13,783 & 42,837 & 97,642 & 156,662 & 229,089 \\
\hline EBITDA & $(1,009)$ & $(1,390)$ & (853) & 6,020 & 24,076 & 47,051 & 74,785 \\
\hline Margin & $-218 \%$ & $-26 \%$ & $-6 \%$ & $14 \%$ & $25 \%$ & $30 \%$ & $33 \%$ \\
\hline Net income & $(822)$ & $(2,685)$ & $(2,640)$ & $(2,341)$ & 2,509 & 9,664 & 18,818 \\
\hline Total assets & 11,016 & 24,750 & 56,246 & 96,584 & 158,948 & 221,002 & 289,882 \\
\hline Total debt & 6,941 & 9,288 & 24,161 & 65,371 & 110,913 & 160,210 & 206,369 \\
\hline Stockholders' equity & 6,155 & 13,887 & 30,547 & 26,806 & 39,075 & 46,499 & 63,077 \\
\hline Capital expenditures & 6,480 & 11,634 & 19,896 & 57,162 & 64,830 & 78,972 & 87,717 \\
\hline Number of stores & 9 & 32 & 72 & 187 & 317 & 475 & 650 \\
\hline
\end{tabular}




\section{TURNING POINT}

The feverish activity of private equity investments in start-up companies peaked when the U. S. economy began turning downward in early 2000. The technology companies, in general, were not performing up to the hyped expectations. Losses and bankruptcies proliferated. Accordingly, investors became disenchanted. The IPO market completely dried up, almost overnight. Seemingly all of a sudden, there was no equity capital to be had anywhere.

Laundromax reached a critical turning point in the Spring of 2000. Rapid expansion was consuming capital at a ravenous pace. The company had 36 stores open and another 3 under construction; however, most had not reached maturity and were not in a positive cash flow position. The company clearly needed additional capital to continue on the established path of a large-scale roll-out of super stores across the country. In fact, the company needed more capital just to reach the next stage. The company had projected that it needed to have 100 stores operating at a mature stage in order to begin generating a profit as a company.

After surveying the existing investors and realizing their lack of appetite for further investment, management turned to the investment banking community. They engaged a well-known investment banker, who expressed solid confidence they could raise $\$ 20$ million in new equity capital. They designed a convertible preferred stock and priced it at $\$ 3.50$, with a $6.75 \%$ dividend. After shopping the deal throughout its network, the investment bank failed to attract investors. Lowering the price per share and sweetening the terms of the security didn't help. The equity market was simply dry.

Recognizing the crunch they were in, management circled around every conceivable way to squeeze through this crisis. They consulted with creditors seeking possible work-out solutions. They held a shareholder meeting to discuss the company's plight. They consulted with attorneys regarding potential legal consequences and alternatives. No "silver bullets" appeared on the horizon.

\section{THE CONUNDRUM}

A central question loomed. Where had the company miscalculated? The founders were both bright and capable professionals with unusual energy and drive. They had done extensive research and carefully modeled every aspect of the business before launching the venture. They were supported by a highly experienced and diversified board of directors who all had their own money at stake. Approximately 85 sophisticated investors had invested $\$ 17$ million after thoroughly studying the business plan. Sophisticated banks were extending credit totaling \$24 million. Among these groups, no one had questioned the soundness of the business strategy or the progress of the concept development. To the contrary, the company received continuous plaudits from multiple audiences for its innovation and implementation. So what went wrong?

There was a more important question, however. What should the company do at this stage? Here are some of the alternatives considered by the board of directors:

1. Hunker down. Halt all store development, trim overhead to the bone, attempt to reorganize debt and buy some time. Try to weather the storm until the economy improved and the capital markets became more favorable. This was a gamble, of course - one that might dig an even deeper hole.

2. Franchise the entire business. This concept would transfer store ownership and debt to potential franchisees (if indeed there was such a market) and potentially relieve the cash flow problem. It would represent a material departure from the established strategy for the company.

3. Resort to vulture capital. Turn to outrageous capital sources that would essentially require the owners to relinquish full control of the company and virtually obliterate existing shareholder interests.

4. File for Chapter 11 bankruptcy protection. Bankruptcy would ward off the creditors and give the company a chance to develop a reorganization plan, which probably would disallow further growth in the near future. This alternative had reputation consequences for management and the board.

5. Simply surrender. Liquidate the company by selling off the stores and other assets at deep discounts, leaving enough cash to pay off all the creditors and hopefully leaving some nominal return of capital to the investors. 


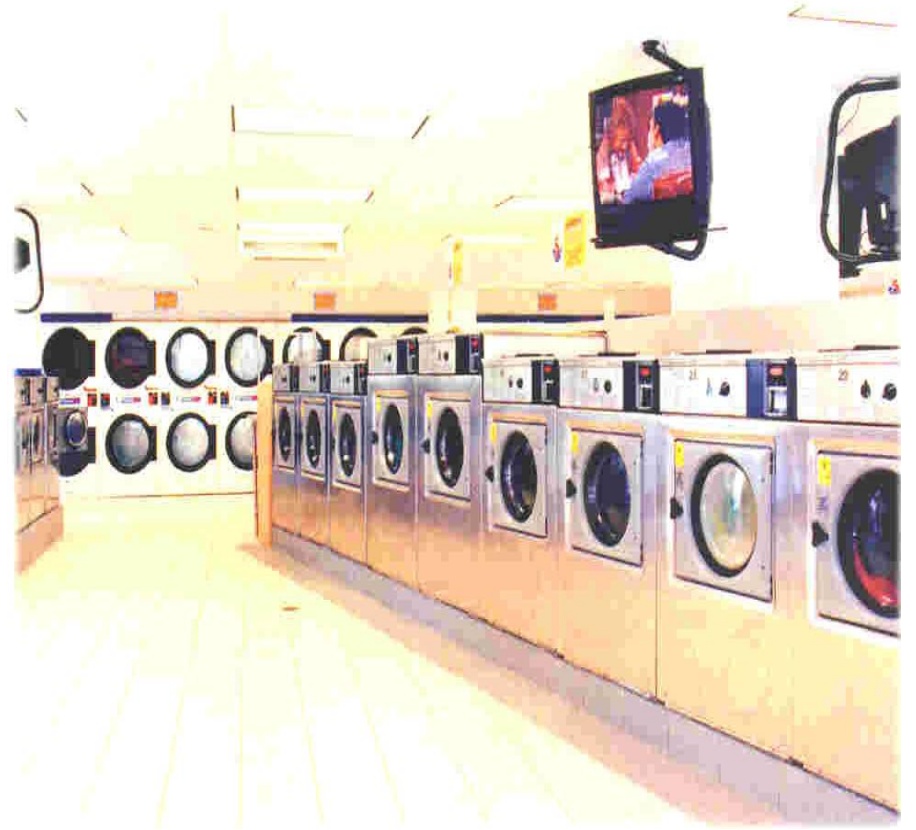

Note: The actual names of executives and directors in this case study have been disguised. 


\section{NOTES}

